\title{
Early and long-term outcomes of pericardiotomy in the treatment of primary cardiac tamponade
}

\author{
Bartłomiej Perek ${ }^{1}$, Iga Tomaszewska², Sebastian Stefaniak ${ }^{1}$, Agnieszka Bartczak $^{2}$, Marek Jemielity ${ }^{1}$ \\ ${ }^{1}$ Department of Cardiac Surgery and Transplantology, Poznan University of Medical Science, Poznan, \\ Poland \\ 2I Department of Cardiology, Poznan University of Medical Science, Poznan, Poland
}

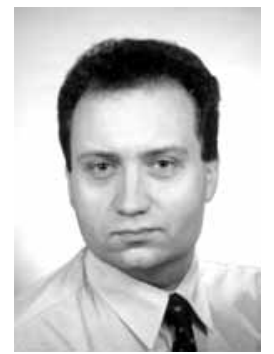

Kardiochirurgia i Torakochirurgia Polska 2015; 12 (3): 191-194

\begin{abstract}
Introduction: Cardiac tamponade is a life-threatening clinical entity that requires emergent treatment. A variety of therapeutic methods have been applied. The purpose of this retrospective analysis was to study the efficacy of emergent surgical pericardiotomy in both the relief of cardiac tamponade and in the prevention of recurrence of pericardial effusion.

Material and methods: This study involved 90 consecutive patients (58 males and 32 females) with a mean age of 57.4 \pm 14.1 years, who underwent emergent pericardiotomy in the years 2006 to 2011 due to symptomatic primary cardiac tamponade. At the end of the follow-up period all living subjects had control echocardiographic examination. Survival analysis was performed with the use of the Kaplan-Meier method.

Results: The mean duration time of surgery was $14.2 \pm 4.5$ minutes. All patients survived surgery but one died during inhospital stay. During the post-discharge follow-up period (median 49 months) 32 patients died for any reason. One-year and four-year probability of survival was $0.68 \pm 0.05$ and $0.64 \pm$ 0.05 , respectively. Malignancy diagnosis was associated with significant negative impact on survival. One-year and fouryear probability of survival was $0.56 \pm 0.06$ and $0.53 \pm 0.06$ for cancer patients while it was $0.93 \pm 0.05$ and $0.89 \pm 0.06$ for the others, respectively. In two cases, only cancer patients, reintervention due to effusion recurrence was necessary.

Conclusions: Pericardiotomy, although invasive, is a safe method to relieve cardiac tamponade. It is also very efficient in the prevention of recurrence of pericardial effusion, even in cancer patients.
\end{abstract}

Key words: cardiac tamponade, pericardiotomy, effusion recurrence, survival.

\section{Streszczenie}

Wstęp: Tamponada serca jest stanem zagrożenia życia, który wymaga leczenia w trybie nagłym. W leczeniu tamponady stosuje się wiele metod. Celem retrospektywnego badania była analiza skuteczności nacięcia worka osierdziowego w trybie nagłym pod względem zarówno uwolnienia tamponady serca, jak i zapobiegania nawrotowi płynu w worku osierdziowym. Materiat i metody: Badaniem objęto 90 kolejnych chorych (58 mężczyzn i 32 kobiety) średnio w wieku 57,4 \pm 14,1 roku, których w latach 2006-2011 poddano perikardiotomii w trybie nagłym z powodu objawowej pierwotnej tamponady serca. Na zakończenie okresu obserwacji u wszystkich chorych wykonano kontrolne badanie echokardiograficzne. Analizę przeżycia przeprowadzono z zastosowaniem metody Kaplana-Meiera. Wyniki: Średni czas trwania zabiegu wyniósł 14,2 \pm 4,5 minuty. Wszyscy chorzy przeżyli operację. Jedna osoba zmarła we wczesnym okresie pooperacyjnym. W okresie obserwacji poszpitalnej (mediana 49 miesięcy) 32 chorych zmarło z jakiejkolwiek przyczyny. Prawdopodobieństwo przeżycia 1 roku i 4 lat po operacji wyniosło, odpowiednio, 0,68 $\pm 0,05$ i 0,64 $\pm 0,05$. Rozpoznanie nowotworu złośliwego miało negatywny wpływ na przeżycie. I tak, oszacowane prawdopodobieństwo przeżycia 1 roku i 4 lat po operacji wyniosło $0,56 \pm 0,06$ i 0,53 $\pm 0,06$ dla chorych z nowotworem złośliwym oraz $0,93 \pm 0,05$ i 0,89 $\pm 0,06$ dla pozostałych. $W$ dwóch przypadkach, i to tylko z nowotworem złośliwym, zaszła konieczność reinterwencji w okresie poszpitalnym ze względu na nawrót płynu w worku osierdziowym.

Wnioski: Perikardiotomia, choć jest zabiegiem inwazyjnym, jest bezpieczną metodą leczenia tamponady serca. Skutecznie zapobiega również nawrotom płynu w worku osierdziowym, w tym również u chorych z nowotworem złośliwym.

Słowa kluczowe: tamponada, nacięcie osierdzia, nawrót choroby, przeżycie. 


\section{Introduction}

Cardiac tamponade is a life-threatening clinical entity that requires emergent treatment [1]. These patients are usually referred to cardiac surgical departments. A variety of methods have been applied in the treatment of these cases ranging from needle pericardiocentesis, through balloonbased techniques and pericardiotomy, to open surgical pericardiectomy [2-4]. The first one is without any doubt minimally invasive and may be performed even in the patient's room, while the latter two must be done in the operating theatre and a complete surgical and anaesthetic team is involved. However, we must bear in mind at least three aims of applied treatment such as emergent relief of cardiac compression, prevention of effusion re-accumulation, and eventually, to a much lower degree, its diagnostic value [5]. More invasive methods are usually associated with lower risk of pericardial fluid re-accumulation, especially in neoplastic patients [6]. In the current era of minimally invasive surgical procedures a crucial issue should be addressed if we are still justified to perform subxiphoid pericardiotomy in the treatment of acute cardiac tamponade.

The purpose of this retrospective study was to evaluate the safety and efficacy of emergent subxiphoid pericardiotomy in both the treatment of cardiac tamponade and the prevention of recurrence of pericardial effusion.

\section{Material and methods \\ Patients}

This study involved 90 consecutive patients (58 males and 32 females) with a mean age of $57.4 \pm 14.1$ years (ranging from 20 to 83 years), who were treated emergently in the years 2006 to 2011 due to symptomatic primary cardiac tamponade. Only patients presenting typical clinical symptoms (e.g. arterial hypotension, tachycardia, dyspnoea, jugular venous distention, pulsus paradoxus) and echocardiographic signs of tamponade (i.e. diastolic right ventricular collapse) were included in this study. Patients with asymptomatic pericardial effusion and these with cardiac tamponade after recent cardiac interventions ('secondary tamponade') as well as terminally ill cancer patients were excluded. On admission, particular attention was paid to possible reasons for pericardial effusion that had led to symptomatic cardiac tamponade.

\section{Surgical procedure}

All surgical procedures were performed emergently. After confirmation of cardiac tamponade in transthoracic echocardiography (M+2D+Doppler) followed by necessary preparations, patients were immediately transferred to the operating theatre where, under general anaesthesia, they underwent pericardiotomy. A skin incision 4 to $6 \mathrm{~cm}$ in length was made, subcutaneous tissues and xyphoid process were dissected free, and after pericardium was identified a hole in it of $2 \mathrm{~cm}$ diameter was made. Pericardial effusion was evacuated intraoperatively and one drain 28 to $32 \mathrm{Fr}$ in diameter was placed for at least 72 hours. If necessary, the pleural cavities were also drained. In all cases pericardial effusion was analysed (macroscopic assessment, biochemical, microbiological, and cytological examinations). After surgery, if no fluid was detected in control echocardiography on the third postoperative day, the drains were then removed. In the majority of patients, additional workup was done to reveal the cause of tamponade, either in our department or in the regional hospitals.

\section{Follow-up period}

After discharge, all patients underwent systematic follow-up in an outpatient clinic. Charts with medical history of all patients were carefully reviewed. At the end of the follow-up period all living subjects had control transthoracic echocardiography (M+2D+Doppler).

\section{Data management and statistical analysis}

Continuous variables were checked for normality using the Shapiro-Wilk $W$ test. Normally distributed continuous data are presented as means with standard deviations (mean \pm SD) and were compared by means of Student $t$ test, while the others (e.g. follow-up period) are presented as medians with the minimal and maximal values (median [min, max]). Categorical variables are presented as the numbers with percentages ( $n[\%]$ ). Survival analysis for the whole group as well as two subgroups (neoplastic and nonneoplastic patients) was performed with the use of KaplanMeier method, and probability of survival was presented as the respective curves. The curves were compared with the use of the Gehan's Wilcoxon test. $P$ values below 0.05 were considered as significant. Statistical analysis was carried out in Statistica 9.0 for Windows (Tulsa, OH, USA).

\section{Results}

\section{Surgery and in-hospital stay}

On admission, in the majority of examined patients ( $n=47 ; 52.2 \%)$ the aetiology of cardiac tamponade was unknown, in 27 individuals (30.0\%) it was related to previously diagnosed malignant neoplasm (particularly of the lungs [ $n=15]$ and breast $[n=9])$, in $8(8.9 \%)$ it was associated with pericarditis, in 5 (5.6\%) with heart failure, and in $3(3.3 \%)$ with end-stage renal dysfunction.

The mean duration of surgery (i.e. skin-to-skin time) was $14.2 \pm 4.5$ minutes. The maximal time was 24 minutes in an extremely obese (BMI 36) 21-year-old man who was referred to our centre from another cardiac surgical department after a failed attempt to perform percutaneous pericardiocentesis, due to technical problems. In 24 patients, including 14 with previously diagnosed lung cancer, at least one pleural cavity also had to be drained.

All patients survived surgery. One patient with lung cancer died on the seventh day after surgery due to progressive respiratory insufficiency and eventually multi-organ failure. In one case, the pericardial drain had to be repositioned because of persistence of pericardial effusion posterior to the left ventricle in the control echocardiography. 
During the repeat surgery, a larger drain was placed below the posterior wall of the heart. A control echocardiography on the fourth postoperative day revealed no effusion, and then the drain was removed. The mean time of pericardial active drainage was $97 \pm 12$ hours. On the day following drain removal, patients were usually discharged from the cardiac surgical department.

\section{Laboratory findings}

Based on laboratory examinations pericarditis was confirmed in seven cases, including two patients with tuberculosis. Moreover, in 25 individuals atypical cells were found in pericardial fluid. Among them there were three patients in whom cytological examination was the first one to reveal any malignancy. Atypical cells of lung cancer in two subjects and of thyroid gland in one case were diagnosed. Further studies confirmed the preliminary diagnoses established on the basis of pericardial effusion laboratory examinations.

\section{Post-discharge follow-up}

During the post-discharge follow-up period, 32 patients died of any reason, the majority of them $(n=29)$ during the first postoperative year. The median follow-up period for the whole group was 49 months (range 0-118 months) and was completed by 88 patients (97.8\%). However, this period was 60 months for survivors (45-118 months). Overall, three-month, one-year, and four-year probability of survival were $0.81 \pm 0.04,0.68 \pm 0.05$, and $0.64 \pm 0.05$, respectively (Fig. 1).

In 33 tamponade patients of unknown aetiology (70.2\%) on admission, malignant neoplasm was eventually diagnosed. Malignancy diagnoses, both established before surgery and during follow-up period, were associated with a significant negative impact on survival. In non-cancer patients only three patients died, all due to complications following purulent pericarditis. One-year and four-year probability of survival was $0.56 \pm 0.06$ and $0.53 \pm 0.06$ for neoplasm patients (group N) and $0.93 \pm 0.05$ and $0.89 \pm$ 0.06 for the others (group O) ( $p=0.0009$ in the Gehan's Wilcoxon test), respectively (Fig. 2).

Echocardiographic examination done at the end followup $(n=55)$ showed complete healing of pericardial effusion in 46 patients (83.7\%) and a small amount of localised fluid (up to $5 \mathrm{~mm}$ ) in other six cases (11.0\%). Moreover, in two cases, only cancer patients, re-interventions due to effusion recurrence were necessary. Thus, the need for reintervention was significantly influenced by the aetiology. Although in many individuals the pericardium appeared to be thickened in echocardiography as compared to healthy human beings, nobody developed symptomatic constrictive pericarditis.

\section{Comments}

First, we should again stress that our study involved only patients with symptomatic cardiac tamponade that required emergent intervention. We are aware of the fact that only a minority of patients with pericardial effusion manifest clinical tamponade that is considered as the highest degree of severity in the spectrum of haemodynamic compromise $[1,7,8]$. For instance, in the Colombo study the prevalence of cardiac tamponade was $44 \%$ among patients with large pericardial effusion, while in the series by Sagristà-Sauleda it was only $37 \%[9,10]$. The selection of our patient group may explain why only a small percentage of them had chronic inflammatory disease or end-stage renal failure. The majority of individuals of the aforementioned groups do not develop clinical symptoms of tamponade in spite of a significant volume of effusion accumulated in the pericardial sack [1]. Patients with chronic effusion are usually well adopted (the pericardium is not uncommonly distended) and may be treated electively instead of on an emergent basis. The findings of our study that patients with malignancy dominate among tamponade cases support earlier reports [10]. Probably, a relatively short period

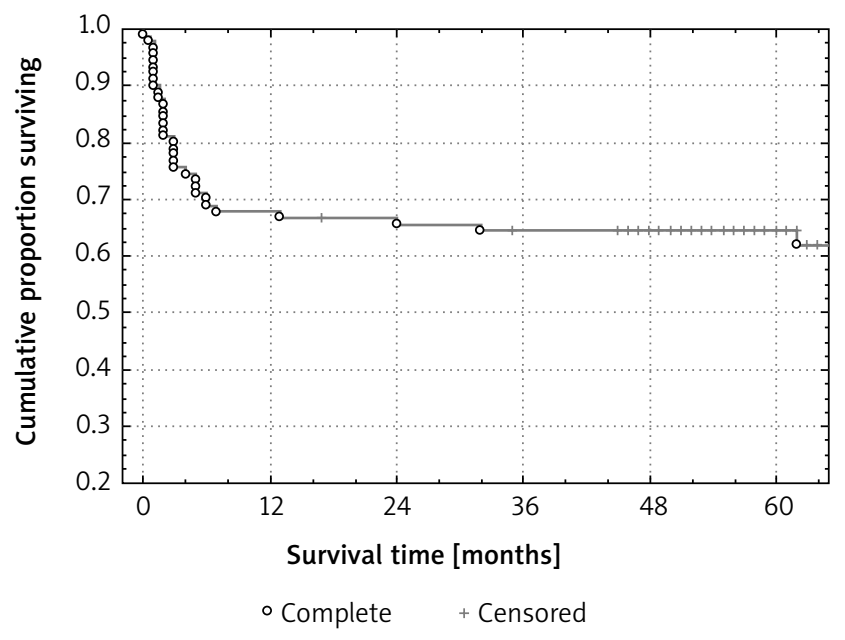

Fig. 1. Probability of survival after surgery for cardiac tamponade

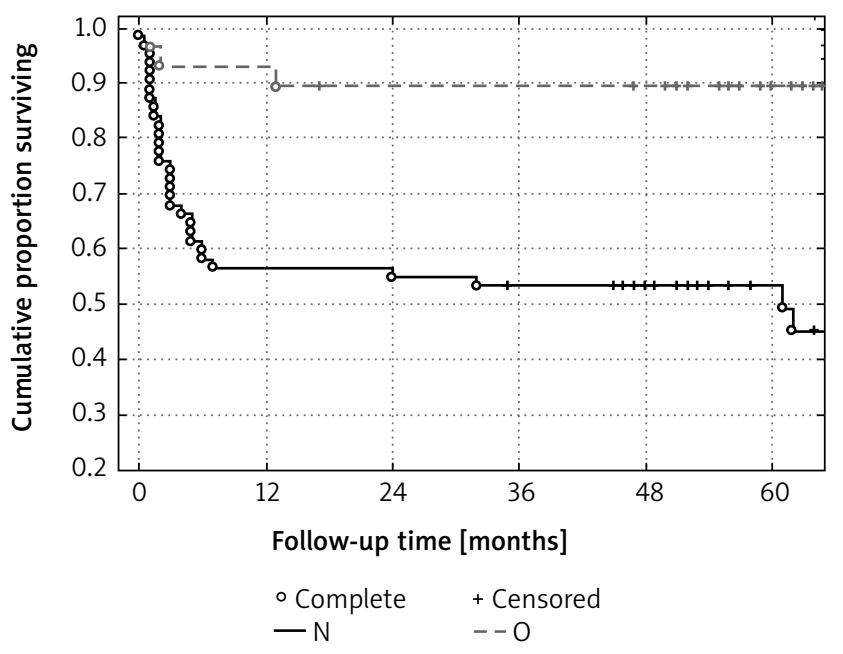

Fig. 2. A comparison of survival probability between patients with and without malignant neoplasm

$p<0.05$

$\mathrm{N}$ - patients with malignant neoplasm, $\mathrm{O}$ - other patients 
of effusion accumulation is responsible for clinical manifestation.

The crucial goal of tamponade treatment is safe drainage of the pericardial effusion. So far, many procedures have been proposed $[2,4]$. Although Guidelines on the Management of Pericardial Diseases published in 2004 recommended pericardiocentesis as the method of choice, the selection of a particular method is largely determined by the aetiology of the tamponade $[1,11,12]$. Because in our group, the predominant reason was malignant neoplasm featured by high risk of fluid re-accumulation, we treated them aggressively. In these patients, simple needle pericardiocentesis, although minimally invasive with the lowest risk of periprocedural morbidity and mortality, is associated with as much as 50\% effusion recurrence [2]. The exception was terminally ill patients with disseminated cancer, but they were not included in our study. In our study we proved that even in cancer patients a relatively invasive subxiphoid pericardiotomy could be a short and safe procedure. Only one patient died throughout the in-hospital stay. Other authors reported markedly higher mortality rates [1]. This may be related to experience, both surgical and particularly aesthetic, in this technique because this procedure has been performed routinely by our team for many years. The second purpose of the treatment is prevention of effusion re-accumulation. Our findings confirmed earlier reports that surgical pericardiotomy is the best method to prevent disease recurrence, particularly in malignant cases. In our series only in two cases repeat procedures were necessary. However, we must remember about two issues of paramount importance in surgical pericardiotomy. First of all, we must be sure that the drain position is correct. This means that complete drainage of the pericardial sack must be achieved. Daily transthoracic echocardiography should be treated as the method of choice to control pericardial space in the early postoperative period. In our series we had to replace the drain only once due to suboptimal location. Second, the pericardial drains should be kept long enough to provoke adherences between the epicardium and pericardium, which is crucial for prevention of fluid reaccumulation throughout the follow-up period. In the majority of our cases, the duration of active drainage ranged from four to five days, which is similar to treatment with indwelling pericardial catheters $[1,13]$.

It is commonly accepted that the prognosis of patients with cardiac tamponade depends on the underlying aetiology $[9,10,14]$. It is especially poor in patients with pericardial effusion secondary to cancer. Moreover, the presence of malignant cells in pericardial fluid obtained during surgery has a negative impact on late survival. Our study confirmed a marked deference in survival between cancer-associated tamponade patients and the others. Another group of patients with rather poor prognosis are those with purulent pericarditis related to underlying debilitating diseases such as widespread infection, poorly controlled diabetes mellitus, or liver cirrhosis. In our group three non-cancer subjects who died during the follow-up period presented this subset of patients.

\section{Conclusions}

The subxiphoid pericardiotomy, although invasive, is a safe method to relieve cardiac tamponade. It is also very efficient in the prevention of pericardial effusion recurrence, even in cancer patients.

\section{Disclosure}

Authors report no conflict of interest.

\section{References}

1. Sagristà-Sauleda J, Mercé AS, Soler-Soler J. Diagnosis and management of pericardial effusion. World J Cardiol 2011; 3: 135-143.

2. Vaitkus PT, Herrmann HC, LeWinter MM. Treatment of malignant pericardial effusion. JAMA 1994; 272: 59-64.

3. Swanson N, Mirza I, Wijesinghe N, Devlin G. Primary percutaneous balloon pericardiotomy for malignant pericardial effusion. Catheter Cardiovasc Interv 2008; 71: 504-507.

4. Piehler JM, Pluth JR, Schaff HV, Danielson GK, Orszulak TA, Puga FJ. Surgical management of effusive pericardial disease. Influence of extent of pericardial resection on clinical course. J Thorac Cardiovasc Surg 1985; 90 : 506-516.

5. Mercé J, Sagristà-Sauleda J, Permanyer-Miralda G, Soler-Soler J. Should pericardial drainage be performed routinely in patients who have a large pericardial effusion without tamponade? Am J Med 1998; 105: 106-109.

6. Refaat MM, Katz WE. Neoplastic pericardial effusion. Clin Cardiol 2011; 34: 593-598.

7. Mercé J, Sagristà-Sauleda J, Permanyer-Miralda G, Evangelista A, Soler-Soler J. Correlation between clinical and Doppler echocardiographic findings in patients with moderate and large pericardial effusion: implications for the diagnosis of cardiac tamponade. Am Heart J 1999; 138: 759-764.

8. Reddy PS, Curtiss EI, Uretsky BF. Spectrum of hemodynamic changes in cardiac tamponade. Am J Cardiol 1990; 66: 1487-1491

9. Colombo A, Olson HG, Egan J, Gardin JM. Etiology and prognostic implications of a large pericardial effusion in men. Clin Cardiol 1988; 11: 389-394.

10. Sagristà-Sauleda J, Mercé J, Permanyer-Miralda G, Soler-Soler J. Clinical clues to the causes of large pericardial effusions. Am J Med 2000; 109: 95-101.

11. Lestuzzi C. Neoplastic pericardial disease: Old and current strategies for diagnosis and management. World J Cardiol 2010; 2: 270-279.

12. The Task Force on the Diagnosis and Management of Pericardial Diseases of the European Society of Cardiology. Guidelines on the Diagnosis and Management of Pericardial Disease. Eur Heart J 2004; 25: 587-610.

13. Patel AK, Kosolcharoen PK, Nallasivan M, Kroncke GM, Thomsen JH. Catheter drainage of the pericardium. Practical method to maintain long-term patency. Chest 1987; 92: 1018-1021.

14. Levine MJ, Lorell BH, Diver DJ, Come PC. Implications of echocardiographically assisted diagnosis of pericardial tamponade in contemporary medical patients: detection before hemodynamic embarrassment. J Am Coll Cardiol 1991; 17: 59-65. 